The Cambridge University press has indicated that its production schedule will be delayed by the current British power crisis. Its production staff is allowed to operate only three days per week and mails are running very slow because of a railroad strike. In fact the airmail letter in which IJMES was notified of this took three weeks to arrive in Los Angeles. Copies of IJMES therefore will be delayed until the crisis has passed. Cambridge University Press and the editor will do everything possible to get the Journal to you as soon as possible.

\title{
Cal1 for Papers and Panels for the 1974 Annual Meeting
}

The 1974 annual meeting of the Association will be held in the Statler-Hilton Hotel in Boston, Massachusetts, from November 6 through.9, 1974. Ms. Barbro Ek of the Middle Eastern Center at Harvard University is handiing the local arrangements.

The Program Committee consists of Professor Paul Ward English, Center for Middle Eastern Studies, University of Texas, Austin, Texas, 78712, coordinator, and James Bill, University of Texas, Irene Gendzier, Boston University, and William Hanaway, University of Pennsylvania, members.

Professor Charles Adams of McGill University has agreed to serve as carryover member.

Those wishing to submit suggestions for papers or for entire panels or symposia, or make any other suggestions concerning the content or format of the annual meeting, should communicate with professor English. Those wishing to organize a panel or a symposium should think in terms of organizing from 4 to 6 people, and collecting titles and abstracts from them for submission to the program Coordinator. Those who wish to present a paper should submit a title and an abstract to the program Coordinator. All this material should be in the hands of the Program Committee by April 1 , 1974 .

\section{Suggestions for the Nominations Committee}

The Nominations Committee charged with preparing the slates for the 1974 elections to MESA offices is chaired by Professor J.C. Hurewitz of Columbia University. The other members are Richard Antoun of SUNY-Binghamton, Farhad Kazemi of New York University and John Masson Smith of the University of California-Berkeley.

Suggestions for nominations can be made to the Chairman or to any other member of the Committee, which will meet in the early spring. 
A new international association--The World Population Society-- was recently organized to encourage study of world population dynamics and its implications for the quality of life. The group will focus on the global aspects of population through an interdisciplinary approach. Dr. Cargille, the newly elected president, stated that the Society will foster research and will publish scholarly works on population problems, as well as sponsor regional and international meetings.

Among "the Society's objectives are the stimulation of international cooperation toward solution of population and environmental problems, the establishment of an information analysis center, the encouragement of disciplines to consider their relevance to population dynamics and the support of the teaching of population science. The Society will also seek to promote recognition of population science as a discipline and to provide for public education and information.

Members will be solicited from numerous fields, includint the social, biomedical, management and information sciences.

"Global Dialogue of the Disciplines on Population" was the theme of the first annual meeting held in Washington, D.C. February 7-9, 1974. The meeting included sessions on the following:

Population and World Human Needs

Influencing population Trends

Is there an optimum Population?

Urbanization: Positive and Negative Implications

What are the Feasible Transitions from Population Growth to Equilibrium?

Technological Progress and Cultural Values

Population and Sustainable Standards of Living: The World Budget of Proteins, Energy and Metals

Pollution - A Possible Mode of Extinction?

Population, Politics and Social Justice

Information about membership and Society activities is available from Dr. Charles Cargille, The World Population Society, The American University, Washington, D.C. 20016. (301) 496-5310, (301) 496-5541, or (202) 686-2174.

Now available upon request are copies of Frank Joseph Shulman's recently published bibliography AMERICAN AND BRITISH DOCTORAL DISSERTATIONS ON ISRAEL AND PALESTINE IN MODERN TIMES. This work brings together for the first time 530 postwar dissertations dealing in whole or in part with the land of Israel since the early $1800^{\prime} \mathrm{s}$. As such it encompasses doctoral research dealing with such subjects as Palestine under the British mandate, the zionist movement in Europe and the United States, the revival of Hebrew as a modern language, and the communal settlements known as kibbutzim and moshavim, as well as the growth of the State of Israel since 1948, various aspects of the Palestinian Arab language and culture, developments on the West Bank (Jordanian Palestine) before and after June 1967, and the continuing Arab-Israeli conflict. All disciplines of academic interest are included, and the theses are classified according to subject and are listed within each section chronologically by date of acceptance. An author index as well as complete information on the best means for acquiring copies of the dissertations themselves are provided. For free copies of this bibliography, please write directly to: Mrs. Bonnie M. Davis; Xerox University Microfilms, 300 North Zeeb Road, Ann Arbor, Michigan 48106 (USA). 
Robert M. Lawrence and Norman Wengert, Professors of Political Science, Colorado State University, Fort Collins, have edited the November issue of THE ANNALS entitled "Energy Crisis: Reality or Myth?" Single copies may be purchased by writing to The American Academy at 3937 Chestnut St., Philadelphia, Pa. 19104. Nonmembers \$3.00; Members \$2.50.

The following works have been published by CRESM (Centre de Recherches et d'Etudes sur les Societes Mediterraneennes):

B. Munier. La Banque Nationale pour le Développement Economique et 1 'Industrialisation du Maroc. 1967.

M. Flory, B. Etienne, J.C. Santucci, G. Fouilloux. La Succession d'Etat en Afrique du Nord. 1967.

A. Adam. Casablanca. Essai sur la transformation de la société Marocaine au contact de 1TOccident. 2 Vol. (2e edition) 1972.

B. Etienne. Les problemes Juridiques des Minorités Europeennes au Maghreb, 1968.

A. Cauneilie, Les Chaamba. Leur Nomadisme. Evolution de la Tribu durant 1 'Administration Francaise. 1968.

J. Couleau. La Paysannerie Marocaine. 1968 (épuis6).

Ch. Debbasch, R.P. Sanson, R.P. Lelong, N. Sraieb, B. Etienne, J.P. Colin, Ch. Souriau. Mutations culturelles et Cooperation au Maghreb. 1969.

J.L. Miege. Doquments d'Histoire Economique et Sociale Marocaine au XIXe siecle. 1969 .

Ch. Souriau. La Press Maghrebine. 1969

Ch. Debbasch, J. Leca, A. Remili, O. Marais, J. Waterbury, A. Khatibi, M. Rousset, L. Ben Salem, A. Zghal, R.E. Germann. Pouvoir et Administration au Maghreb. Etudes sur les Elites Maghrebines. 1970 .

Ch. Debbasch, G. Destanne de Bernis, M. Adam, P. Valberg, J. Poncet, J. Ch. Asselain, A A. Belal, A. Agourram, B. Etienne, L. Talha. Les Economies Maghrebines. L'Independence a l'Epreuve du Developpement Economique, 1971.

M. Camau. La Notion de Democratie dans la Pensee des Dirigeants Maghrebins. 1971

R. Le $\overline{\text { Tourneau, }}, A$. Benyoussef, B. Etienne, N. Sraieb, J.C. Sanrucci, M. Flory. L'Unité Maghrebine. Dimensions et Perspectives. 1972 .

C. Camilleri. Jeunesse, Famille et Developpement. Essai sur le Changement Socioculturel dans un pays du Tiers Monde (Tunisie). 1973 .

M. Teitler, A. Nouschi, M. Camau, B. Etienne, N. Sraieb, J.C. Santucc1 J.J. Regnier, O. Marais, J. Leca. Elites, Pouvoir et Legitimite au Maghreb. 1973

The first volume of HUMANIORA ISLAMICA, the Annual publication for Islamic Studies and the Humanities (published by Mouton Press, The Hague), appeared in the fall, 1973. It includes sections on"North Africa"'"Mediaeval Islam,"Turkish Islam and other Cultures, "and"The State of Islamic studies. Volume Two of this work is due to appear Fall 1974 and will include the following sections: "On history and Anthropology in the Study of Islam," "Early and Mediaeval Islam," "Modern Islam," and "Reflections." For general information write: Humaniora Islamica, Suite 500, Boston University, 270 Bay State Road, Boston, U.S.A.

The IDOC (International Documentation on the Contemporary Church) of North America, in collaboration with the Arab-Israeli Research and Relations Project, recently published a new quarterly on the Middle East. The special September 1973 issue was entitled "Controversy in the Middle East; U.N. Resolution 242: An E1usive Hope for Peace?" The subscription rate is $\$ 10.00$ per year. For further information write: IDOC-North America, 235 East 49 th St., N.Y.,N.Y. 10017.(212) 752-5121. 
The International Labour office has published Employment and Income Policies for Iran. 1973, priced at $\$ 12.00$. For information write: United States: ILO Branch Office, llth floor, Room 1100, 666 Eleventh St., NW, Washington, DC, 20001; Canada: ILO Branch Office, 3rd floor, Room 307, 178 Queen St., Ottawa 4, Ontario; United Kingdom: ILO Branch, Sackville House, 40 Piccadilly, London W1V 9PA.

The International Publications Service announces the publication of two books: the 5th edition of WHO'S WHO IN LEBANON, $1973,820 \mathrm{p}$. Cloth, price-\$35.00; RECORD OF THE ARAB WORLD, YEARBOOK OF ARAB AND ISRAELT POLITICS, 19732 volumes, c 1,600p., price $\$ 70.00$. For information write: International publications Service, 114 East 32nd Street, New York, N.Y. 10016.

Vol. V, No. 4 of IRANIAN STUDIES has recently been published and includes articles by H.J. Rotblat, S.S. Lieberman, book reviews by M.B. Loraine, J.R. Perry, R. Taylor, and a directory of teachers of Persian in the U.S. and Canada compiled by M.A. Jazayery. For information write: Secretary of the Society for Iranian Studies, P.O. Box 89, Village Station, New York, N.Y. 10014, U.S.A.

The Tehran Book Processing Centre of the Institute for Research and Planning in Science and Education announces the publication of the English edition of the IRANIAN PERIODICAL DIRECTORY, 1972-1973, prices at \$4.00. Send check or money order (include postage) to: Tehran Book Processing Centre (TEBROC), P.O. Box 11-1126, Tehran, Iran.

Haya Gratch has recent1y edited TWENTY-FIVE YEARS OF SOCIAL RESEARCH IN ISRAEL, A Review of the Work of the Israel Institute of Applied Social Research in the Years 1947-1972. The cost of the book is $\$ 12.00$. Send all requests to: Jerusalem Academic Press, P.O.B. 2390, Jerusalem, Israel.

The Middle East Research \& Information Project has published the following reports:

7 US and Jordan: The Thrice-Rescued Throne--the relationship between the US and the Hashemite Monarchy, and how and why the US has bolstered it against nationalist Jordanian and palestinian political pressures

15 Socialist Revolution in Arabia: Report from Democratic Yemen--a first-hand report on recent revolutionary developments in the People's Democratic Republic of Yemen

16 Pakistan's Role in US World Strategy--a study of the interrelationships among pakistan, Iran and Israel, with special focus on why the US supported West Pakistan in the Bangladesh war

17 Retreat of the Revolution in Egypt--the political significance of developments in Egypt through spring, 1973; Notes from Inside Israel--a first-hand report on the life of the palestinians living under Israeli occupation

18 Iran: Ten Years after the "White Revolution"--the political, social and economic roots of Iran's present "economic miracle," and an explanation of Iran's place in US global strategy 
19 Student protests and the Coming Crisis in Lebanon--how student protests are rooted in economic and political distortions caused by Lebanon's dependence on Western powers $\$ .50$

20 Middle East Oil and Energy Crisis: Part I-- historical analysis of the US oil industry in the Middle East to $1960 \$ .50$

21 Middle East 0 il and the Energy Crisis: Part II--analysis of developments in Middle East oil since 1960 and the oil company strategy behind the "energy crisis" campaign

22 The October War--a study of developments in Egypt, Syria, and Israel leading up to the war in October 1973 and prognostications for the future

23 US Policy and the October War--an account of the rigidity of US policy from 1967 to October 1973, and the new pressures forcing adaptation upon Kissinger as a result of that war

For information write: MERIP, Box 3122, Columbia Heights Station, Washington, D;C; 20010 or MERIP, Box 48, Harvard Square Station, Cambridge, Mass. 02138.

The AMERICAN INSTITUTE OF IRANIAN STUDIES announces the names of its new officers and executive committee:

president

professor T. Cuyler Young, Jr.

Princeton University

Vice President

Professor Rouhollah K. Ramazani

University of Virginia

\section{Secretary}

Professor Louis D. Levine

Royal Ontario Museum

Treasurer

Mr. Charles J. Scheidt, Jr.

First National Bank, Chicago

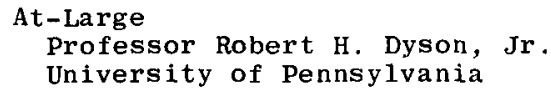

\section{At-Large}

Professor Emeritus T. Cuyler Young

Princeton University

Director of the Tehran Center

Dr. Jerome W. Clinton, A.I.I.S.

Address correspondance to:

The President and the Secretary: or West Asian Department Royal Ontario Museum 100 Queen's Park Toronto, Ontario Canada M5S 2C6 (Telephone : 416-928-3683)

The Director of the Tehran Center :

Kiaban Moshtaq 9 P.O. Box 11-1885

Tehran, Iran

(Telephone: 42488) 
The following were elected to the Council of the SOCIETY FOR IRANIAN STUDIES for 1974:

Ervand Abrahamian, Baruch College, C.U.N.Y.

Amin Banani, University of California at Los Angeles

James A. Bill, University of Texas at Austin

Ali Banuazizi, Boston College

Jerome W. Clinton, American Institute of Iranian Studies

Gene R. Garthwaite, Dartmouth College

Paul W. Eng Lish, University of Texas at Austin

Farhad Kazemi, New York University

Kenneth A. Luther, University of Michigan

Ann Schulz, Clark University

The TURKISH STUDIES ASSOCIATION announces the names of its officers for 1974:

President

Kemal H. Karpat

University of Wisconsin at Madison

Honorary President

Dankwart A. Rustow

Brooklyn College, CUNY Graduate Center

Secretary

Joseph S. Szyliowicz

University of Denver

Treasurer

Sidney Fisher

(formerly of Ohio State University)

Board of Directors

Roderic Davison

George Washington University

I lhan Bashgoz

Indiana University

John Smith

University of California at Berkeley

Richard Chambers

University of Chicago

The Center for Middle Eastern Studies, University of Texas at Austin, invites the submission of manuscripts based on scholarly research in the field of Middle Eastern studies. Such manuscripts will be considered for publication in a series of books which the Center is sponsoring in cooperation with the University of Texas Press. Preference will be given to studies involving the late 19 th and 20 th centuries, with any disciplinary focus.

Inquiries and manuscripts should be addressed to the Editorial Board, Center for Middle Eastern Studies, University of Texas at Austin, Austin, Texas 78712 .

$-80-$ 
Dr. Taha Hussein died in Cairo on October 28, 1973, at the age of eighty-four. He had received the United Nations human rights prize the day before. A memorial tribute was read at the annual meeting of the Middle East Studies Association in Milwaukee by Prof. Roger Allen of the University of Pennsylvania. An obituary appears in the October 29, 1973 edition of the New York Times.

Dr. Otha L. Clark, a fellow of the Association, died in October 1973 at the age of sixty-six. 